\title{
Erigeron pacalis (Asteraceae), a New Species from Western Canadian Boreal Grasslands
}

\author{
Curtis R. Björk \\ Beaty Biodiversity Museum, 2212 Main Mall, University of British Columbia, Vancouver, British \\ Columbia V6T 1Z4, Canada. crbjork@gmail.com
}

ABSTRACT. Erigeron pacalis Björk (Asteraceae) is a new species found only in the Peace River Grasslands of northeastern British Columbia, Canada. Its characteristics (short stature, leathery leaves, vestiture of mixed glandular and nonglandular hairs, and white rays) distinguish it from E. glabellus Nutt. and $E$. asper Nutt., the latter of which has appeared only in synonymy under E. glabellus according to most recent authors, but which shows consistent distinctions that merit its resurrection from synonymy.

Key words: Asteraceae, British Columbia, Canada, Erigeron, IUCN Red List, Peace River Lowlands.

The Peace Grasslands occupy a region of northeast British Columbia and northwest Alberta, Canada, that is contrastively dry and warm compared to surrounding boreal regions. These grasslands occupy a narrow corridor of south-facing slopes over the Peace River and its tributaries, and are surrounded by a vast plain vegetated by boreal forest. The finding of an undescribed and endemic species of Erigeron L. may be considered improbable given the presumed glacial history of the landscape; the Peace River Valley fits within the region that is thought to have been covered by continental ice sheets in the last glacial maximum. The grassland vegetation of the Peace Grasslands presumably formed in its current composition after the retreat of the Cordilleran and Laurentide ice sheets about 12,000 BP (Pielou, 1991). However, it remains to be determined definitively whether these two ice sheets joined, if a corridor remained vegetated and ice free between them throughout the last glacial maximum, or whether the corridor was closed but contained nunataks isolated on peaks of the foothills nearby (Pielou, 1991). Icefree nunataks may not have harboured grassland species in the Peace River Lowlands, where E. pacalis Björk occurs, but nunataks on peaks of the eastern Rocky Mountain foothills may have served in this role. Even if the Peace Grasslands are vegetated entirely with species that arrived after the end of the glacial maximum, it cannot be ruled out that endemic plants have evolved there since that time, or have evolved in grasslands beyond the glacial-maximum limits of ice cover to the north or south where they subsequently became extirpated. Some regionally endemic vascular plants occupy landscapes that are thought to have been fully engulfed by ice sheets during the last glacial maximum, including a suite of vascular plant taxa known only from sand dune ecosystems near the southern shore of Lake Athabasca in northern Saskatchewan, Canada, around $59^{\circ} \mathrm{N} 109^{\circ} \mathrm{W}$ (Karpan \& Karpan, 1998), and the moss family Pseudoditrichaceae Steere \& Iwatsuki known only from Great Bear Lake, Northwest Territories, Canada. The Peace Grasslands are known to harbour endemic species, including a number of butterfly taxa (Guppy \& Shepard, 2001), as well as additional vascular plants that await publication new to science (Björk, pers. obs.).

Erigeron pacalis Björk, sp. nov. TYPE: Canada. British Columbia: Peace Lowlands, Peace River Valley, $18 \mathrm{~km} \mathrm{~W}$ of Fort St. John, $460 \mathrm{~m}$, $56^{\circ} 14.700^{\prime} \mathrm{N} 121^{\circ} 8.480^{\prime} \mathrm{W}$, 18 July 2008 , fl., C. Björk 115790 (holotype, UBC). Figure 1.

Species nova ab Erigeronte glabello Nutt. statura humiliore, foliis coriaceis, capitulo in quoque caule semper unico, caulibus distaliter et involucro minute glanduliferis atque floribus radii discique brevioribus.

Plants perennial, forming small clumps; caudex branches 2-3 mm thick; roots fibrous; stems simple, 5-7 cm, erect or decumbent, strongly reddish purple pigmented and glabrous proximally, green, hirsute to hirsuto-villous and minutely glandular distally. Basal leaves ascending; petioles strongly reddish purple, ciliate, with stiffly spreading or antrorsely curved hairs $0.25-1.2 \mathrm{~mm}$, intermixed with shorter, finer, ascending hairs; leaf blades entire, coriaceous, narrowly oblanceolate, 40-60 × 4-6 mm, often reddish purple blushed, 3-nerved or those of the narrower leaves 1nerved or obscurely 3-nerved; lateral nerves less prominent than the middle nerve; apex rounded or blunt, often with short, indurate, yellowish mucro; both faces minutely strigillose or glabrate, eglandular, hairs $0.05-0.2 \mathrm{~mm}$; leaf margins with larger, stiffer antrorse hairs; cauline leaves 4 to 7 , gradually reduced distally, 


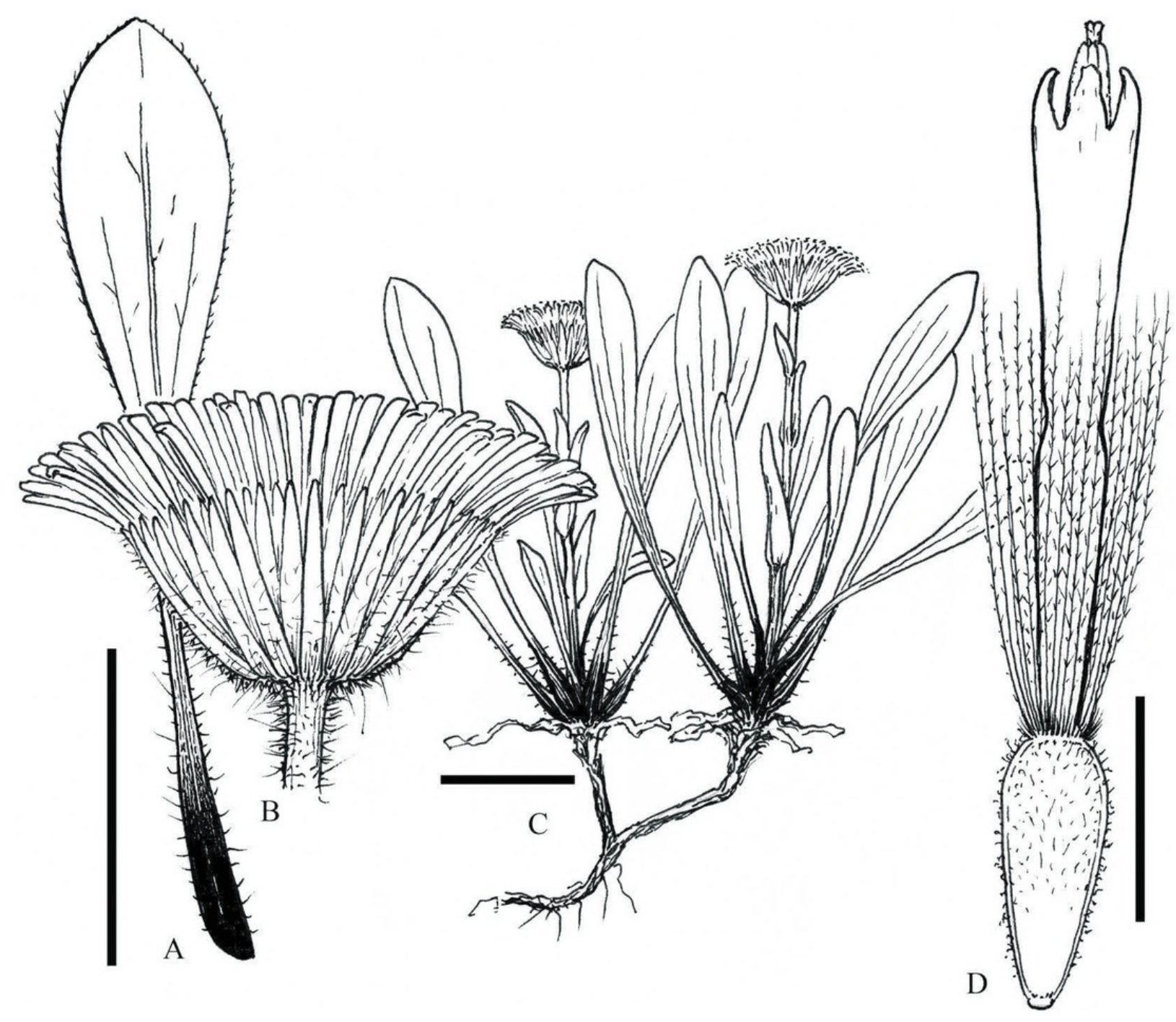

Figure 1. Erigeron pacalis Björk. - A. Basal leaf. —B. Flower head. - C. Plant habit. —D. Disc floret and immature cypsela. Scale bars: A, B $=10 \mathrm{~mm}, \mathrm{C}=20 \mathrm{~mm}, \mathrm{D}=1 \mathrm{~mm}$. Drawn from the holotype C. Björk 115790 (UBC).

proximal leaves spreading, distal leaves appressed to the stem; leaf blades lanceolate, mostly clasping at the base, $9-31 \times 2-3 \mathrm{~mm}$, ciliate proximally with stiffly spreading or antrorsely curving hairs, both faces minutely strigillose, distalmost leaves minutely glandular on both faces. Heads 1 per stem, not or scarcely exceeding the basal leaves; involucres 5-5.5 $\times 12$ $13.5 \mathrm{~mm}$ (pressed); phyllaries in 3 to 4 subequal to unequal series, linear-(ob)lanceolate, acuminate, 1nerved, most with margins narrowly scarious, spreading-hirsute with septate hairs $0.2-0.6 \mathrm{~mm}$, most hairs with 3 to 9 septa, with an underlayer of minute glandular hairs at least distally. Ray florets white, ca. 75 to 100 in number, $5-6 \times 0.3-0.5 \mathrm{~mm}$, not curling; disc florets $2.8-3.5 \mathrm{~mm}$, papery, without distinct ribs, lobes narrowly triangular, erect or incurved. Cypselae ca. $2.2 \times 0.5 \mathrm{~mm}$, obscurely 2-nerved, strigillose, shorter hairs gland-tipped; pappus antrorsely barbellulate of 2 series of unequal members, ca. 30 outer setae, ca. $0.3 \mathrm{~mm}$, and 16 to 18 inner setae, $2.5-3 \mathrm{~mm}$.
Distribution and ecology. Erigeron pacalis is known only from the type locality near Fort St. John in northeastern British Columbia. It occupies boreal grasslands, a geographically rare biome occurring in North America only along east-west-oriented river valleys and in orographic rain shadows in the western boreal zone in British Columbia, Alberta, and the Yukon in Canada, and in Alaska in the United States. The boreal grasslands of the Peace River Valley are located on south-facing slopes along the Peace River between ca. $117^{\circ}$ and $122^{\circ} \mathrm{W}$. The nearest sizeable grasslands are approximately $200 \mathrm{~km}$ distant to the southeast in Alberta. In the Peace River Valley region, E. pacalis grows in patches of open grassland within a boreal forest mosaic. The local soils are fine textured, mixed with gravel and derived from poorly consolidated, calcareous sediment layers. Erigeron pacalis occurs with a variety of grasses and upland Carex L., as well as a large assortment of forbs and shrubby species in patchy grasslands in clearings of Betula 
papyrifera Marshall-Picea glauca (Moench) VossPopulus tremuloides Michx. forest, and in boreal grasslands with Achillea millefolium L., Anemone patens L., Artemisia frigida Willd., Carex duriuscula C. A. Mey., Comandra umbellata (L.) Nutt., Elymus lanceolatus (Scribn. \& J. G. Sm.) Gould, Monarda fistulosa L., Poa cusickii Vasey, and Rosa acicularis Lindl.

IUCN Red List category. Despite searches in grasslands along major portions of the British Columbia area of the Peace River and its major tributaries in 2008 , no additional populations were found. Specimens of all Erigeron species that could be confused with $E$. pacalis (i.e., entire leaved and with non-woolly involucres) were examined at ALTA, CAN, PMAE, UBC, and V. No additional specimens of $E$. pacalis were found in these herbaria. The Peace Grasslands straddle the British Columbia-Alberta border; the Alberta portions of the grasslands have mostly been converted into farmland, and only about $0.5 \%$ of the original grassland area retains goodcondition native vegetation (Baker, 2005). No approximations are available for the portion of the Peace Grasslands in British Columbia that remain in native vegetation, but a major share of the original grassland vegetation has been converted to agriculture, intense grazing, or other human uses, or has otherwise seen major degradation of vegetation condition. Major portions of the Peace Grasslands that have not been converted to agriculture have lost native plant cover as the invasive exotic species Bromus inermis Leyss. and Melilotus (L.) Mill. species continue to spread.

According to IUCN Red List (2001) criteria B2 (geographical range $<10 \mathrm{~km}^{2}$ ) and due to ongoing severe threats from human use of the Peace River Valley, Erigeron pacalis falls under the Critically Endangered (CR) assessment.

Etymology. The species name comes from the Latin for "peace" or "peaceful," named after the Peace River Valley, where the type of the species was collected.

Discussion. Like members of Erigeron sect. Erigeron (Nesom, 2008), E. pacalis is shortstemmed, monocephalous and possessing of glandular hairs. However, the members of that section, unlike $E$. pacalis, have relatively poorly developed cauline leaves and ray corollas that are more distinctly coiling after anthesis. Additionally, in northwestern North America, the members of Erigeron sect. Erigeron are found only in arctic, alpine, and subalpine habitats. Hence, the affinities of $E$. pacalis are presumed to be instead with Erigeron sect. Fruticosus G. Don (Nesom, 2008). Like members of that section, E. pacalis has cauline leaves similar in shape and size to the basal leaves and ray corollas that remain straight or coil only slightly after anthesis. Like E. pacalis, several members of Erigeron sect. Fruticosus grow at lower elevations.

Several characteristics of Erigeron pacalis suggest that it is likely related to E. glabellus (Erigeron sect. Fruticosus), including its grassland habitat, fibrous roots, narrowly oblanceolate leaf shape, well-developed cauline leaves (i.e., cauline leaves similar in shape and size to the basal leaves), and in the indument of hirsute to hirsuto-villous hairs, similar to those of E. glabellus var. pubescens Hook. (although, in addition, there are shorter glandular hairs on E. pacalis). Erigeron pacalis differs from $E$. glabellus in its shorter stature $(5-7 \mathrm{~cm}$ vs. $7-40$ $\mathrm{cm}$ ), in having heads consistently only one per stem (vs. one to 15 heads per stem), glandular hairs on distal parts, coriaceous (vs. softly herbaceous) leaves, and shorter ray and disc florets $(5-6 \mathrm{~mm}$ vs. $8-15 \mathrm{~mm}$ ).

Compared with Erigeron pacalis, most whiterayed individuals of $E$. glabellus, as that species is defined in the Flora of North America (Nesom, 2006), are much taller plants, 30-50(-70) cm, with larger heads (involucres $10-20 \mathrm{~mm}$ wide vs. 12 $13.5 \mathrm{~mm}$ in E. pacalis), and with basal leaves acuminate and usually with prominent white midribs (apices rounded or blunt and midribs not so noticeable and white in E. pacalis). These whiterayed plants are common in the Peace River Grasslands and in the Canadian Prairies (east to Manitoba), and have been referred as E. asper Nutt. in earlier Canadian literature.

Cronquist (1947) synonymized Erigeron asper under E. glabellus, but the distinctions of that species from E. glabellus appear to be more clearly defined than Cronquist might have been aware of. Erigeron asper blooms mostly earlier (May to June) than the June to August flowering periods of $E$. pacalis and pink-flowered forms of E. glabellus, as evidenced by the collection dates reported on herbarium specimen labels, my own field observations in British Columbia, Alberta, and Saskatchewan, and the phenology observations of Scoggan (1979). Occasional white-rayed individuals are sometimes mixed in populations of pink-rayed $E$. glabellus s. str. (i.e., minus E. asper), but I know of no populations having only white rays, and those occasional white-rayed plants lack the other distinctions of E. asper. 
Erigeron glabellus is highly diverse in morphological forms, even after E. asper is segregated. The pubescence types that define the two widely recognized varieties glabellus and pubescens are only one of several characters that potentially could define discrete morphotypes in the species. Much of the diversity of form, however, appears to be due to availability of light and soil nitrogen. Plants in shaded sites and on humus-rich soil are usually tall, lax plants with longer caudex branches, and those in full sun and nitrogen-poor soil are often diminutive, relatively erect, and more caespitose. The possibility was considered that the characteristic small size, monocephalous stems, and leathery leaves of $E$. pacalis represent drought-stress-induced plasticity, but I observed numerous E. glabellus populations in equally dry, sunny conditions in the Peace Grasslands that maintained the characteristics of $E$. glabellus in contrast to those of $E$. pacalis (i.e., taller stature, softly herbaceous leaves, larger flower heads that are often not solitary on the stems, longer rays, and lack of glandular hairs in E. glabellus). Additionally, some populations of E. glabellus observed in the Peace Grasslands on dry, warm south-facing slopes on well-drained soil were as tall, broad leaved and large headed as those growing in cool sites on rich soil in partial shade at forest margins or on river cut-banks.

\section{Key to Erigeron Species of the Peace River Lowlands}

la. Plants short-lived (annual, biennial, or short-lived perennial), lacking a well-developed root crown or rhizomes; ray florets either inconspicuous and barely longer than the disc florets or longer but less than $1 \mathrm{~mm}$ wide $\ldots \ldots .2$

1b. Plants perennial, generally long-lived, with a well-developed root crown or stout rhizomes; ray florets usually

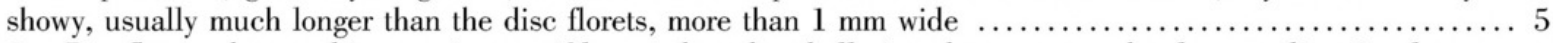
2a. Ray florets short and inconspicuous, if longer than the phyllaries, then erect or shortly spreading; involucre hemispheric to boxy; phyllaries with an abrupt bend, giving the involucre a shouldered appearance $\ldots \ldots \ldots 3$

2b. Ray florets long and conspicuous, much longer than the phyllaries; involucre turbinate or broadly hemispheric; phyllaries more or less straight or gradually curved $\ldots \ldots \ldots \ldots \ldots \ldots \ldots \ldots \ldots \ldots \ldots \ldots$ 3a. Plants of saline or strongly alkaline wetlands; inflorescence usually much longer than wide; rayless unisexual female florets absent between the ray and bisexual disc florets ....... E. lonchophyllus Hook.

$3 \mathrm{~b}$. Plants of woodlands, clearings, trail sides, or wetlands that are not strongly saline or alkaline; inflorescence moderately longer than wide; rayless unisexual female florets present between the ray and bisexual disc florets ... E. acris L. var. kamtschaticus (DC.) Herder [the similar E. elatus (Hook.) Greene also to be sought]. 4a. Rays white, 2-6 mm long; plants with a slender, delicate appearance; basal and stem leaves 3-25

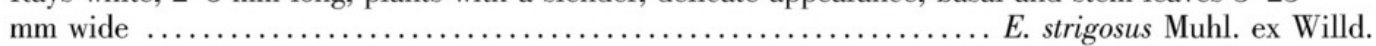

4b. Rays purple or lavender (rarely white), 5-10 mm long; plants stout; basal and stem leaves 15-120

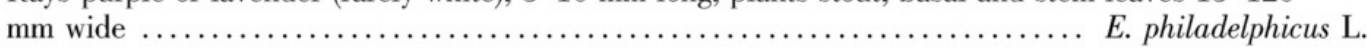
5a. Plants tall (mostly $>3 \mathrm{dm}$ ) and leafy; with no or only inconspicuous basal leaves; stems with large, conspicuous, lanceolate cauline leaves that scarcely reduce in size up the stem ......

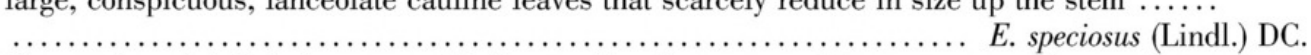

5b. Plants short $(<2 \mathrm{dm})$; stems with few cauline leaves, or with numerous and conspicuous cauline leaves, but then also with a distinct basal rosette $\ldots \ldots \ldots \ldots \ldots \ldots \ldots \ldots \ldots \ldots$ 6a. Leaves deeply divided into threadlike segments ............... E. compositus Pursh

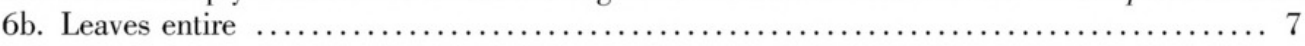

7a. Stems generally with two or more branches; harsh, spreading hairs on stems and leaves; basal leaves not forming distinct rosettes ................ E. pumilus Nutt.

7b. Stems not branched, or with one or occasionally two branches (not including peduncles leading to single flower heads); appressed or spreading hairs on stems, if spreading, then basal leaves forming distinct rosettes $\ldots \ldots \ldots \ldots \ldots \ldots \ldots \ldots \ldots \ldots$

8a. Stems with numerous (mostly $>10$ ) appressed leaves; stems and leaves grayish with dense, appressed hairs; plants usually producing three or more stems per basal leaf cluster; stems usually arching outward from the base $\ldots . \ldots \ldots \ldots$

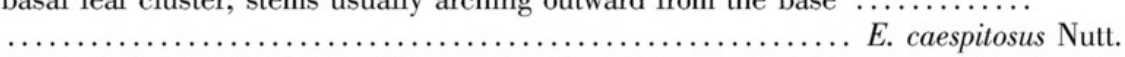

8b. Stems with few (mostly $<10$ ), spreading leaves; stems and leaves green, with sparse to dense, spreading hairs; plants usually producing only one stem per basal leaf cluster; stems erect from the base $\ldots \ldots \ldots \ldots \ldots \ldots \ldots \ldots \ldots \ldots$ 9a. Above-ground stems unbranched; ray florets white; minute glands present on phyllaries, distal cauline leaves and distal portions of stems ....E. pacalis 9b. Above-ground stems often branched; ray florets white, pink or lavender;

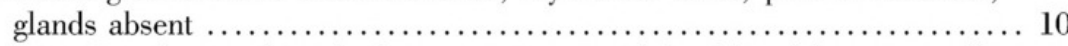

10a. Ray florets white; leaf tip acuminate; midrib of basal leaves usually white and conspicuous; flowering May to June ............. E. asper

10b. Ray florets pink or lavender (or a few individuals albino); leaf tip acute, blunt, or rounded; midrib of basal leaves usually green and not conspicuous; flowering June to August ...... E. glabellus var. pubescens 
Acknowledgments. Jason Hollinger is thanked for his patient tending of Erigeron specimen plantings in the garden. Todd Kohler is appreciated greatly for his fine help in the field. I am grateful to Luc Brouillet, Guy Nesom, and Rick Noyes for their insightful reviews of the manuscript. I also thank the staff of the herbaria ALTA, CAN, PMAE, UBC, and V for facilitating my research.

\section{Literature Cited}

Baker, A. 2005. A synthesis of 2001-2004 Peace native grasslands program. Technical Report (T-2004-002) produced by Alberta Conservation Association, Peace River, Alberta.

Cronquist, A. 1947. A revision of the North American species of Erigeron, north of Mexico. Brittonia 6: 121302.
Guppy, C. S. \& J. H. Shepard. 2001. Butterflies of British Columbia. University of British Columbia Press, Vancouver.

IUCN. 2001. IUCN Red List Categories and Criteria, Version 3.1. Prepared by the IUCN Species Survival Commission. IUCN, Gland, Switzerland, and Cambridge, United Kingdom.

Karpan, R. \& A. Karpan. 1998. Northern Sandscapes. Parkland Publishing, Saskatoon.

Nesom, G. L. 2006. Erigeron. Pp. 256-348 in Flora of North America Editorial Committee (editors), Flora of North America: North of Mexico, Vol. 20: Magnoliophyta. Oxford University Press, New York.

Nesom, G. L. 2008. Classification of Subtribe Conyzinae (Asteraceae: Astereae). Lundellia 11: 8-38.

Pielou, E. C. 1991. After the Ice Age: The Return of Life to Glaciated North America. University of Chicago Press, Chicago.

Scoggan, H. J. 1979. The Flora of Canada: Part 4. Dicotyledoneae (Loasaceae to Compositae). National Museum of Natural Sciences, Publications in Botany, No. 7(4). National Museum of Canada, Ottawa. 


\section{$2 \mathrm{BHL}$ Biodiversity Heritage Library}

Björk, Curtis R. 2013. "Erigeron pacalis (Asteraceae), a New Species from Western Canadian Boreal Grasslands." Novon a journal of botanical nomenclature from the Missouri Botanical Garden 22(3), 271-275. https://doi.org/10.3417/2012030.

View This Item Online: https://www.biodiversitylibrary.org/item/196082

DOI: https://doi.org/10.3417/2012030

Permalink: https://www.biodiversitylibrary.org/partpdf/218569

\section{Holding Institution}

Missouri Botanical Garden, Peter H. Raven Library

\section{Sponsored by}

Missouri Botanical Garden

\section{Copyright \& Reuse}

Copyright Status: Permission to digitize granted by rights holder Rights: https://www.biodiversitylibrary.org/permissions

This document was created from content at the Biodiversity Heritage Library, the world's largest open access digital library for biodiversity literature and archives. Visit BHL at https://www.biodiversitylibrary.org. 